\section{Prudent Policy Of President Shavkat Mirziyoyev In Social Protection And Poverty Reduction}

\section{Yormatov Fahriddin Jaylovich,}

Candidate Of Historical Sciences, Associate Professor, Termez State University, Termez, Uzbekistan

\author{
G OPEN ACCESS \\ The American Journal \\ of Applied Sciences \\ JULY 2020 \\ Page No.: 65-71 \\ Volume-II Issue-VII \\ PUBLISHED: 30 JULY 2020 \\ www.usajournalshub.com/inde \\ x.php/tajas \\ Copyright: Original content \\ from this work may be used \\ under the terms of the \\ Creative Commons Attribution \\ 4.0 licence.
}

\title{
Abstract
}

This article discusses the prudent policy of President Shavkat Mirziyoyev in Uzbekistan on social protection and poverty reduction, as well as the measures being taken to address the problems and shortcomings in this area.

Keywords: Social protection, human, benefit, vulnerable, needy, financial assistance, pensioners, needy, disabled, large families, poverty, employment, humanitarian, marriage, social security, assistance, program, women, children, family business, privilege, credit.

\section{Introduction}

During the years of independence, strong social protection of the population has become a priority of state policy, and a certain amount of work has been done in this direction. "Before the introduction of market mechanisms," said Islam Karimov in his 1992 book "Uzbekistan's own path to independence and development," social protection measures must be taken. A state is considered humane only if it can protect its population. The state should provide timely assistance to people, especially those in need, socially vulnerable, 
orphans, children, students, pensioners and disabled people, single mothers, large and low-income families "[1, p. 41].In particular, the President of the Republic of Uzbekistan Shavkat Miromonovich Mirziyoyev continues this work more consistently, paying special attention to social protection and employment. After the death of the first president, Islam Karimov, during his tenure as prime minister, he began to consider these issues as a priority. Speaking about the relevance of these issues, the President said: "The most important socio-economic task is the implementation of the program to increase employment, approved by the chambers of the OliyMajlis. We need to create over a million new jobs by the end of the year. The employment of 480,000 vocational college graduates requires special scrutiny. We will resolutely pursue the policy of Islam Abduganievich, aimed at reducing the level of social stratification in society, so that our country is neither too rich nor too poor.I consider it my main task to continue the path of consistent independent development of our country in the political, social and economic spheres and the implementation of democratic reforms developed by the First President of the Republic of Uzbekistan, our great leader, respected Islam Karimov and effectively carried out for a quarter of a century "[2].The positive work done by President ShavkatMirziyoyev quickly showed positive results and led to a further increase in citizens' confidence in the future. Speaking about the positive achievements in the field of social protection under the state program for 2016, the President said: "Under this program, about 9 million women of childbearing age and about 10 million children underwent medical examinations and rehabilitation.

In particular, cochlear implantation operations were performed in more than 350 children with hearing impairments at the Republican Specialized Scientific and Practical Medical Center for Children. 21 billionsoumswerespentforthesepurposes. But what matters for us is not how much money is spent, but the health of hundreds of our children.Among these activities, 700,000 children were vaccinated against pneumococcal infection and other infectious diseases.

As part of this program, a lot of work was done to create the necessary conditions for our women, to create modern housing and social infrastructure in rural areas based on standard projects.At the same time, \$100 million. The United States was attracted through foreign investment to provide rural areas with drinking water and modernize water supply networks in districts and cities "[3].

Declaring 2017 the Year of Dialogue with the People and Human Interests in our country is also of great importance. "The main goal of these reforms is to ensure a decent standard of living and quality of life for the population. The main priority is the consistent implementation of the noble idea that "human interests are of paramount importance." Today, the main goal of our life, which is reflected in our Constitution, is to ensure the full protection of human interests. To ensure the interests of people, first of all, it is necessary to communicate with people, with people, to know their worries, dreams, problems and 
needs.People should serve our people, not government agencies, and this fact should be well understood by leaders at all levels "[4]. The fourth direction of the "Strategy of actions for five priority directions of development of Uzbekistan for 2017-2021" [5], adopted on February 7, 2017, is called "Priorities for the development of the social sphere", which provides for the implementation of the following. - increase real income and purchasing power of the population, further reduce the number of low-income families and the level of income inequality;

-созданиеновыхрабочихместизанятостинаселения, особенновыпускниковсреднихспециальныхивысшихучебныхзаведений, обеспечениесбалансированногоразвитияlabormarketinfrastructure, reducingunemployment;

- improving the system of social protection and health care, increasing the socio-political activity of women;

- Ensuring mandatory social guarantees for the population, strengthening social protection of the poor and state support for the elderly and disabled, improving social services, developing public-private partnerships in the provision of social services to the population; - increasing the socio-political activity of women, strengthening their role in governing the state and society, ensuring the employment of women, graduates of professional colleges, their wide participation in entrepreneurial activity, further strengthening the family base;

- further development and improvement of the system of medical and social assistance to pensioners, disabled people, lonely elderly and other low-income groups of the population to ensure their full life;

The President also noted the need to improve the living conditions of the population, especially young families, people living in dilapidated houses, and other people in need of housing through the provision of concessional mortgages and the construction of affordable housing in urban and rural areas. is a prime example of sound policy in this area.Regarding the work done in 2017, the President said: "During 2017, the issue of creating new jobs, which is very important for us, has always been at the center of our attention. In 2017, more than 336,000 new jobs were created due to the construction of new industrial enterprises, commissioning of service facilities, development of small business and private entrepreneurship.

Obviously, we have prioritized employment, so we need to pay special attention not only to quantity but also to quality.

The implementation of the adopted programs for reforming the social sphere is being gradually ensured, which is a very important direction of state policy in Uzbekistan. It is known that the problem of housing has been tormenting our population for a long time, especially workers in the public sector, families with low income. There is a fact that we have almost ignored this serious social problem. Taking into account the needs and 
desires of our people, this year we launched a project to build affordable housing based on a soft mortgage.

In total, more than 3.5 million square meters have been built in our cities and villages. $M$ standard houses and multi-storey buildings. If we compare this figure with previous years, we see that 20 times more houses were built than in 2007, 3.5 times more than in 2010, when the standard housing program was launched, and 2 times more than in 2014. It is worth noting that for the first time in the past 25 years, we began to build affordable, multi-storey housing for the population.In 2017 alone, more than 800,000 square meters of such housing were built and commissioned. Only in Tashkent this year 420,000 square meters of multi-storey housing was commissioned. This is almost three times more than last year "[6].Speaking about further strengthening social protection, the president said: "Economic development and social protection are inextricably linked and cannot be presented separately. Improving the living conditions of the population, providing them with decent housing, improving the well-being of our people will always be in the center of our attention "[7].

By 2019, the scope of such work will increase.

- The procedure for full payment of pensions to working pensioners has been introduced. The amount of benefits for the population in need and in need of social assistance has doubled.

- Last year, 634 private medical institutions were created in connection with the increase in the number of medical events from 50 to 126 and the provision of a number of benefits. "Large-scale construction and improvement works were carried out in 479 villages and auls, 116 city makhallas within the framework of the Obodkishlok and Obodmakhalla programs. - 17,100 houses were built in rural areas, 17,600 in cities, which is a total of 34,700 , or almost 3 times more than in 2016. - More than 116 billion soums were paid to 5,000 low-income families in need of improved housing, including women with disabilities, to purchase affordable housing on the basis of mortgage loans. The reforms we are carrying out are highly appreciated by the international community.In particular, one of the world's leading publications, the Economist magazine, recognized Uzbekistan as the country with the fastest reforms in 2019 - "Country of the Year".

Speaking about the positive work to be done in 2020, the President said: "In 2020, 5.5 thousand women will be provided with soft loans in the amount of 100 billion soums for small business projects. For this we allocate resources to banks from the state budget.In addition, 1,576 women will receive an initial contribution from the budget for the purchase of new housing. The training of our sisters in need of social protection at the centers of women's entrepreneurship will be organized in the form of short training courses within the framework of 5 important initiatives "[8]. We all must have a deep understanding of one point: the priorities that we have set for ourselves are very complex and truly enormous goals. 
At the same time, the world is changing over time, and the demands of our people for a better life are growing. Now we cannot please our people with yesterday's result.Today, every day requires research and innovation. Only by working on the basis of such requirements can we change the lives of our people for the better. The President is also actively working to reduce poverty in Uzbekistan. The President of the Republic of Uzbekistan ShavkatMirziyoyev held a video conference on February 27, 2020 on measures to reduce poverty through the development of entrepreneurship. , This is not true. Unfortunately, according to preliminary estimates, 4-5 percent of our population is poor. Now we do not need to hide, we need to understand the real problem, the position of our people living in difficult conditions, to change the worldview of all categories of leaders.According to our data, Kashkadarya region is the worst in terms of poverty. 700,000 people are poor. This is about 21 percent of the total population. In this situation, the leaders of Kashkadarya cannot sit still. He must ask himself the question of how we can get our people out of such a difficult situation. In addition, 500,000 people are poor in the Republic of Karakalpakstan, 500,000 in the Surkhandarya region, 400,000 in the Namangan region, 210,000 in the Jizzakh region and 130,000 in the Syrdarya region. If we take these numbers in terms of neighborhoods, we see heavier numbers.For example, in the Yangiabadmahalla, Parkent district, there are 1,039 low-income and poor people. 906 people in the Mirshodimahalla of the Altynsay region and 504 people in the Toda mahalla of the Boysun region are in a difficult situation.Studying poverty in Uzbekistan requires specific measures. It is important to study the experience of developed countries. In 2020, Uzbekistan will implement programs to reduce poverty in the amount of $\$ 700$ million. This was noted by the President of Uzbekistan ShavkatMirziyoyev in his speech at the celebration of International Women's Day.

Poverty reduction has been identified as a priority in Uzbekistan, and we have begun to implement large-scale measures in this direction. We need to clearly understand one fact - in order to reduce poverty, we must first reduce unemployment. First of all, it is necessary to educate the population in modern professions, to increase their economic and financial literacy, to inspire people, especially women, for entrepreneurship, the President said. Poor 4-5 million people, their daily income does not exceed 10-13 thousand soums.

On March 26, 2020, the President of the Republic of Uzbekistan ShavkatMirziyoyev approved Decree No. PF-5975 on measures to radically update state policy in the field of economic development and poverty reduction. According to the decree, 100 billion soumswill be allocated to the Ministry of Economic Development and Poverty Reduction in 2020 to finance measures to reduce poverty.President of the Republic of Uzbekistan ShavkatMirziyoyev also raised the issue of supporting vulnerable groups of the population at a video conference on April 20 this year. It was noted that it is necessary to identify families who are temporarily unemployed and in need of assistance, and to expand the 
provision of food and medicine on a targeted basis. As well as fighting the disease, countries are doing everything they can to keep jobs and prevent a sharp economic downturn. take the initiative to create a movement.On May 13, 2020, a video conference was held under the chairmanship of ShavkatMirziyoyev on mitigating the negative impact of the coronavirus pandemic on living standards and the economic sector. At the meeting, special attention was also paid to the issue of social protection. "The tasks were set to ensure the rights of workers of quarantine institutions, citizens in quarantine, and their carers, to increase the number of social pensioners by at least $10 \%$ or 60,000 people. Parents caring for their children in quarantine receive temporary disability benefits. At a time of decline in economic activity, the problem of employment requires special attention. Therefore, an additional 200 billion soums will be allocated from the anti-crisis fund to the Public Works Fund "[9].The videoconference was held on July 8, 2020 under the chairmanship of ShavkatMirziyoyev. The meeting was devoted to the work carried out to reduce poverty. The head of state noted that "it is necessary to hire at least 257 thousand representatives of low-income families in order to provide loans to 37 thousand households within the framework of family business" [10].

This information can be continued with many other examples.In conclusion, it should be noted that the prudent policy of President ShavkatMirziyoyev in the field of social protection and poverty reduction has led to an improvement in the standard of living and welfare of the citizens of Uzbekistan.

\section{References:}

1. Karimov I. Uzbekistan for a great future. - Tashkent: Uzbekistan, 1998. 41p.

2. Speech by the Prime Minister of the Republic of Uzbekistan ShavkatMiromonovichMirziyoyev at a joint meeting of the Legislative Chamber and the Senate of the OliyMajlis. September 8, 2016.

3. Speech by the elected President of the Republic of Uzbekistan ShavkatMirziyoyev at the ceremony dedicated to the 24th anniversary of the adoption of the Constitution of the Republic of Uzbekistan. December 7, 2016.

4. Report of the President of the Republic of Uzbekistan ShavkatMirziyoyev at an expanded meeting of the Cabinet of Ministers on the main results of the country's socioeconomic development in 2016 and the most important priorities of the economic program for 2017. 15 January 2017.

5. Strategy of actions on five priority directions of development of Uzbekistan for 20172021, adopted on February 7, 2017.

6. Regular Message of the President of the Republic of Uzbekistan ShavkatMirziyoyev to the chambers of the OliyMajlis. December 22, 2017. 
7. Regular Message of the President of the Republic of Uzbekistan ShavkatMirziyoyev to the chambers of the OliyMajlis. 28 December 2018.

8. Regular Message of the President of the Republic of Uzbekistan ShavkatMirziyoyev to the chambers of the OliyMajlis. January 25, 2020.

9. People'sword. May 14, 2020.

10. People'sword. July 9, 2020. 